\title{
Implementation Plan of the Clinical Practice Guideline for the Early Detection, Diagnosis and Treatment of Patients With Alcohol Abuse or Dependence in a Colombian Hospital
}

\author{
Jhasnny Moreno Reales ${ }^{1}$, Eduardo Navarro-Jiménez ${ }^{2}$, Carmen Laborde-Cárdenas ${ }^{2}$, \\ Pedro Gómez-Méndez ${ }^{3}$ \& Luis Carlos Luque Narvaez ${ }^{4}$ \\ ${ }^{1}$ Instituto de Medicina Legal de Colombia, Quibdó, Chocó, Colombia \\ ${ }^{2}$ Facultad de medicina, Programa de Medicina, Universidad Simón Bolívar, Barranquilla, Colombia \\ ${ }^{3}$ Facultad de ciencias de la salud, Programa de psiquiatría, Universidad del Norte, Barranquilla, Colombia \\ ${ }^{4}$ Departamento de Gestión Organizacional, Universidad de la Costa CUC, Barranquilla, Colombia \\ Correspondence: Eduardo Navarro-Jiménez, Universidad Simón Bolívar, Barranquilla, Colombia. Orcid: \\ http://orcid.org/0000-0002-8171-662X E-mail: edunavjim@gmail.com
}

Received: July 14, 2018 Accepted: July 29, 2018 Online Published: August 11, 2018

doi:10.5539/gjhs.v10n9p89 URL: https://doi.org/10.5539/gjhs.v10n9p89

\begin{abstract}
Objective: Implement a Clinical Practice Guideline for the early detection, diagnosis and treatment of the acute phase of intoxication of patients with alcohol abuse or dependence in the priority consultation services and outpatient consultation of the E.S.E Cari Neurosciences Hospital of the city of Barranquilla.

Introduction: Alcoholism is the first drug addiction in many countries of the world. It affects all ages, both sexes and in almost all social groups. Alcohol is estimated to cause nearly $4 \%$ of deaths worldwide and is one of the top 20 causes of disability-adjusted life years (DALYs), either due to associated neurological and / or psychiatric conditions $(38 \%)$, accidental injury $(28 \%)$ or intentional injury $(12 \%)$. In Colombia, alcohol consumption is widely accepted and promoted. The life prevalence of psychoactive substance use disorders is $10.6 \%$, and alcohol abuse is the most prevalent disorder.

Materials and Methods: An implementation plan for a management CPG for the early detection, diagnosis and treatment of an acute phase of intoxication of patients with alcohol abuse or dependence will be developed, according to the manual methodology of implementation of guidelines Clinical practice based on evidence from the Colombian Ministry of Health.

Conclusions: The CPGs contain recommendations with the best clinical evidence available. Therefore, it is necessary that they be adopted by users, for which it is necessary to follow the dissemination, dissemination and implementation plan, address the intrinsic and extrinsic obstacles and facilitators of the CPGs and monitor the indicators described to measure the process of implementing CPGs in clinical practice.
\end{abstract}

Keywords: alcoholism, clinical practice guide, communication barriers

\section{Introduction}

Alcoholism is the first drug addiction in many countries in the world. It affects all ages, both sexes and in almost all social groups. It is the direct cause of more than half of car accidents (Cenetec, 2013).

The abuse of alcoholic beverages and alcohol dependence represent a serious public health problem worldwide, both because of the economic and social costs generated by society, and because of the effects on individuals and families. According to the World Health Organization, 3.3 million deaths occur worldwide each year due to the harmful consumption of alcohol, which represents $5.9 \%$ of all deaths. The consumption of alcohol causes deaths and disability at a relatively early age. Between 20 and 39 years, 25\% of deaths are attributable to alcohol consumption. Alcoholism is not only a causative agent of several serious diseases, but also a catalyst for aggressions and violent situations (Alwan, 2011)

Alcohol is carcinogenic and increases the risk of cancer of the mouth, esophageal (throat), laryngeal, liver and breast, in the case of women; and to a lesser extent cancer of the stomach, colon and rectum, in that order. The 
annual risk of death from cancers related to alcohol consumption (mouth, pharynx, throat and liver) increases from 14 per 100 thousand for middle-aged abstainers and 50 per 100 thousand for drinkers with four or more drinks per day (40g of alcohol). Currently, there is strong evidence that alcohol increases the risk of breast cancer in women. At age 80, the risk increases from 88 for every 1,000 abstaining women to 133 for every 1,000 women who consume six drinks per day (60g of alcohol). It is very likely that alcohol increases the risk of breast cancer due to the increase in hormone levels, which are known to be a risk factor for this type of cancer (Organización Panamericana de la Salud OPS/ OMS, 2008).

In the country, alcohol consumption is widely accepted and promoted: According to the National Mental Health Survey, the prevalence of life of disorders due to the use of psychoactive substances is $10.6 \%$. Alcohol abuse is the most prevalent disorder. It is estimated that one in 15 Colombians abuses alcohol, with a male to female ratio of 5 to 1 (Alcaldía de Barranquilla, González Martínez, \& Granados De la Hoz, 2014)

In 2013, it was reported that the average age of onset of alcohol consumption in Colombia was 15.9 years, an average higher than that obtained in the 2008 study (Yokoyama et al., 2015). The age of onset of substance-related disorders is between 18 and 26 years, with an average age of onset of alcohol abuse at 23 years, and the highest rate of current use is among young people aged 18 to 24 years, which they constitute the largest proportion of subjects with harmful consumption or risk of alcohol. The lifetime prevalence of alcohol abuse is $6.8 \%$ and dependence $2.4 \%$ (Dirección Nacional de Estupefacientes, 2008).

The 2003 National Mental Health Study showed that only one in ten people with a mental disorder received psychiatric care. These limitations on access to mental health services have been addressed and in recent years improvements have been made in the laws that govern this issue, positively influenced by the purpose of achieving universality in the affiliation to all Colombians General Social Security System (Ministerio de Salud y Protección social, 2005; Posada-Villa, José A.; Aguilar-Gaxiola, Sergio A; Magana, Cristina G, Gomez, 2004).

In the 2007 National Health Survey, access to mental health services was studied from a domain that uniquely involved the search for and the start of care. In this survey it was evidenced that only $0.8 \%$ of the attention received was due to illness or mental, nervous or behavioral problems; In contrast, the results of the last study of disease burden for Colombia refer to the first twenty causes according to total DALY's (x1000 people), and within them it is evident that of these twenty causes four are from the group of mental illnesses (Peñaloza Quintero, Salamanca Balen, Rodríguez Hernández, Rodríguez García, \& Beltrán Villegas, 2014).

\section{Methods}

This research developed a Plan for the implementation of a management CPG for the early detection, diagnosis and treatment of the acute phase of intoxication of patients with alcohol abuse or dependence at the ESE Cari Neurosciences Hospital of Barranquilla, according to the methodology of manual of implementation of clinical practice guidelines based on evidence from the Ministry of Health (Duarte Osorio, Torres Amaya, \& Vélez, 2014). Although in Colombia there is a CPG for the management of early detection, diagnosis and treatment of the acute phase of intoxication of patients with alcohol abuse or dependence developed by the Ministry of health and social protection (Centro Nacional de Investigación en Evidencia y tecnologías en salud Cinets, 2013); A rigorous methodological search was conducted to review CPG - according to evidence - based medicine - of alcohol dependency management that have a considerable clinical quality to be implemented in the ESE Cari Neurosciences of Barranquilla (Peñaloza Quintero et al., 2014). For the identification of evidence-based clinical practice guidelines $(\mathrm{CPG})$ to be implemented, systematic searches were made of international databases of development organizations or compilers of clinical practice guidelines, and databases that collected scientific literature on subjects related to clinical practice. abuse or dependence on alcohol (see Table 1). To search for local guides, psychiatrists specialized in the management of this pathology in the city of Barranquilla (who had an employment relationship with the ESE Cari Mental Hospital and the academy) were asked to report on the existence of clinical practice guidelines based on the evidence of its use and knowledge. The following search structure was used in English: • "Guidelines as Topic" [Mesh]) OR ("Practice Guidelines as Topic" [Mesh])) OR ("Guideline" [Publication Type])) OR ("Practice Guideline" [Publication Type])) OR (guideline [Title / Abstract])) AND (adapt* [tw] OR tailor * [tw]). On the other hand, the terms of most frequent use were adapted to the search in Spanish. The search was filtered to include only clinical practice guidelines. The criteria for inclusion of the CPG were the following:

- Evidence-based guidelines, $\bullet$ Guides developed through a process by an expert group $\bullet$ Guidelines that establish recommendations, $\bullet$ Guidelines whose scope and purpose are related to alcoholism, withdrawal syndrome or acute alcohol intoxication. 22 CPGs met the above criteria. The results are presented in Table 1 
Table 1. Results of the Preselection of clinical practice guidelines

No. Title of the guide

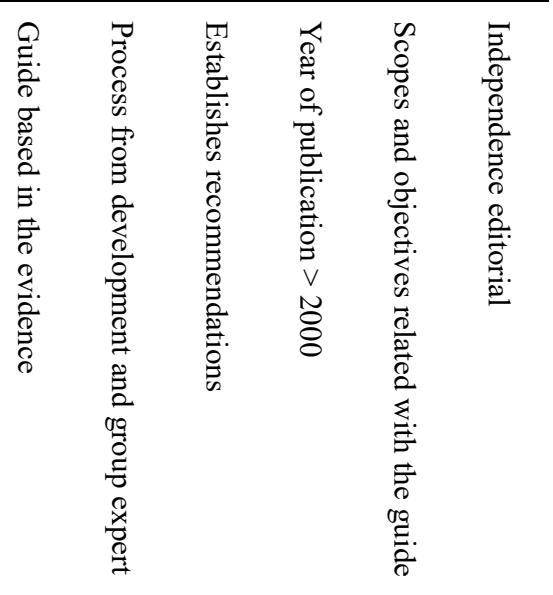

\begin{tabular}{|c|c|c|c|c|c|c|c|}
\hline 1 & $\begin{array}{l}\text { Problem Drinking Part 1: Screening and Assessment Part 2: Brief } \\
\text { Intervention Part 3: Office Based Management of Alcohol Withdrawal and } \\
\text { Prescribing Medications for Alcohol Dependence (Guidelines and } \\
\text { Protocols Advisory Committee, 2013) }\end{array}$ & Yes & Yes & Yes & Yes & Yes & Yes \\
\hline 2 & $\begin{array}{l}\text { Alcohol-use disorders: diagnosis, assessment and management of harmful } \\
\text { drinking and alcohol dependence (National Institute for Health and } \\
\text { Clinical Excellence, 2011a) }\end{array}$ & Yes & Yes & Yes & Yes & Yes & Yes \\
\hline 3 & $\begin{array}{l}\text { Drug and Alcohol Abuse amongst Anaesthetists Guidance on } \\
\text { Identification and Management (The Association of Anaesthetists of Great } \\
\text { Britain \& Ireland, 2011) }\end{array}$ & Yes & Yes & Yes & Yes & Yes & Yes \\
\hline 4 & $\begin{array}{l}\text { EFNS guidelines for diagnosis, therapy and prevention of Wernicke } \\
\text { encephalopathy (Galvin et al., 2010) }\end{array}$ & Yes & Yes & Yes & Yes & Yes & Yes \\
\hline 5 & $\begin{array}{l}\text { Alcohol Use Disorders: Diagnosis And Clinical Management Of } \\
\text { Alcohol-Related Physical Complications-Clinical Guideline } 100 \text { (National } \\
\text { Institute for Health and Clinical Excellence, 2011b). }\end{array}$ & Yes & Yes & Yes & Yes & Yes & Yes \\
\hline 6 & $\begin{array}{l}\text { Alcohol and } \\
\text { Pregnancy A practical guide } \\
\text { for health professionals (Ministry of Health of New Zealand, 2010). }\end{array}$ & Yes & Yes & Yes & Yes & Yes & Yes \\
\hline 7 & $\begin{array}{l}\text { Guidelines for the treatment of alcohol problems (Haber, Lintzeris, } \\
\text { Proude, \& Lopatko, 2009) }\end{array}$ & Yes & Yes & Yes & Yes & Yes & Yes \\
\hline 8 & $\begin{array}{l}\text { Australian guidelines to reduce health risks from drinking alcohol } \\
\text { (National Health and Medical Research Council, 2009) }\end{array}$ & Yes & Yes & Yes & Yes & Yes & Yes \\
\hline 9 & $\begin{array}{l}\text { The Guide to Clinical Preventive Services Task Force - Screening and } \\
\text { Behavioral Counseling Interventions in Primary Care to Reduce Alcohol } \\
\text { Misuse (U.S. Preventive Services Task Force, 2013) }\end{array}$ & Yes & Yes & Yes & Yes & Yes & Yes \\
\hline 10 & $\begin{array}{l}\text { Alcohol consumption and the outcomes of pregnancy (Royal College of \& } \\
\text { Gynaecologists, 2009) }\end{array}$ & Yes & Yes & Yes & Yes & Yes & Yes \\
\hline 11 & $\begin{array}{l}\text { Detoxification and substance abuse treatment: physical detoxification } \\
\text { services for withdrawal from specific substances (U.S. DEPARTMENT } \\
\text { OF HEALTH AND HUMAN SERVICES, n.d.) }\end{array}$ & Yes & Yes & Yes & Yes & Yes & Yes \\
\hline 12 & $\begin{array}{l}\text { Guidelines for the management of alcohol issues in the acute general } \\
\text { hospital setting (Wood, 2008) }\end{array}$ & $\mathrm{Si}$ & $\mathrm{Si}$ & $\mathrm{Si}$ & $\mathrm{Si}$ & $\mathrm{Si}$ & $\mathrm{Si}$ \\
\hline 13 & $\begin{array}{l}\text { Tratamiento de las Complicaciones de la Dependencia al Alcohol (Caja } \\
\text { Costarricense de Seguro Social, 2005) }\end{array}$ & Yes & Yes & Yes & Yes & Yes & Yes \\
\hline
\end{tabular}




\begin{tabular}{|c|c|c|c|c|c|c|c|}
\hline 14 & $\begin{array}{l}\text { Conductas adictivas y patología dual (Area de Gestión Clínica de } \\
\text { Psiquiatría y Salud Mental - Hospital Universitario } 12 \text { de Octubre, 2016) }\end{array}$ & Yes & Yes & Yes & Yes & Yes & Yes \\
\hline 15 & $\begin{array}{l}\text { Diagnóstico e tratamento de comorbidades psiquiátricas e dependencia de } \\
\text { álcool (Zaleski et al., 2006) }\end{array}$ & Yes & Yes & Yes & Yes & Yes & Yes \\
\hline 16 & Management of Alcohol Withdrawal Delirium (Mayo-Smith, 2004) & Yes & Yes & Yes & Yes & Yes & Yes \\
\hline 17 & $\begin{array}{l}\text { Evidence-based guidelines for the pharmacological management of } \\
\text { substance misuse, addiction and comorbidity: recommendations from the } \\
\text { British Association for Psychopharmacology (Lingford-Hughes, Welch, \& } \\
\text { Nutt, 2004) }\end{array}$ & Yes & Yes & Yes & Yes & Yes & No \\
\hline 18 & $\begin{array}{l}\text { The management of harmful drinking and alcohol dependence in primary } \\
\text { care. A national clinical guideline (SIGN 74, 2015) }\end{array}$ & Yes & Yes & Yes & Yes & Yes & Yes \\
\hline 19 & $\begin{array}{l}\text { Tratamiento Hospitalario del Síndrome de Deprivación Alcohólica } \\
\text { (Monte-Secades, Rabuñal-Rey, \& Guerrero-Sande, 2015) }\end{array}$ & Yes & Yes & Yes & Yes & Yes & Yes \\
\hline 20 & $\begin{array}{l}\text { Guidelines for Recognising, Assessing and Treating Alcohol and Cannabis } \\
\text { Abuse in Primary Care (National Health Committee, 2011) }\end{array}$ & Yes & Yes & Yes & Yes & Yes & Yes \\
\hline 21 & $\begin{array}{l}\text { Guía de práctica clínica para la detección temprana, diagnóstico y } \\
\text { tratamiento de la fase aguda de intoxicación de pacientes con abuso o } \\
\text { dependencia del alcohol (Centro Nacional de Investigación en Evidencia y } \\
\text { tecnologías en salud Cinets, 2013) }\end{array}$ & Yes & Yes & Yes & Yes & Yes & Yes \\
\hline 22 & $\begin{array}{l}\text { Diagnóstico y Tratamiento De la intoxicación aguda por Alcohol etílico en } \\
\text { el Adulto en el Segundo y Tercer Nivel de Atención (Cenetec, 2013). }\end{array}$ & Yes & Yes & Yes & Yes & Yes & Yes \\
\hline
\end{tabular}

\section{Results}

The final decision to adopt a Hospital Practice Guideline was based on the selection of a guide that had a similar object population to that of ESE Cari Mental and that was easily available: Clinical practice guide for the early detection, diagnosis and treatment of the acute phase of intoxication of patients with alcohol abuse or dependence. This Guide was designed in 2013 for what is new and considers the current legal regulations of the General System of Social Security in Health (SGSSS) (Ministerio de Salud y Protección Social, Fundación Santafe, Grupo de actualización de la Guía Metodológica para el desarrollo de Guías de Práctica Clínica, \& Colombiano Evaluación Económica en el SGSSS, 2014)

The respondents that have management of the Colombian CPG explained in their majority:

1). Based on the Colombian context, unlike other CPG-depression, such as the Chilean, Spanish and Mexican, to name a few examples.

2). The Colombian CPG has 3 years of elaboration. Some guides, on the other hand, have up to 10 years since their last update, when it is not recommended that they be more than 5 years.

3). It is based on the MBE (medicine based on evidence).

4). It is written in Spanish, which if not, could have become a barrier to adopting the CPG

The group of experts considered the following barriers to the implementation of CPG - alcohol:

- Difficulties in accessing ESE Cari Mental. The ESE Mental Hospital is the only public hospital in the department. It is at Barranquilla, so the user population may find it difficult to travel to receive specialized care.

- Little availability of specialized professionals. In Colombia there are not enough professionals who have the appropriate training in the diagnosis, psychotherapy and psychopharmacotherapy proposed in CPG-alcohol, and those who are available are not equally distributed among the user population. This situation would prevent following the recommendations in this Guide.

- The limited time in the primary care consultation, which would hinder the application of some of the CPG alcohol recommendations (AUDIT screening scales, brief motivational intervention).

- The lack of applicability of some recommendations, due to the clinical situation in which the patient is located, where there may not be availability of some medications (such as intravenous lorazepam), or recommended paraclinical studies (serum levels of vitamin B12 and folic acid), or the possibility of transfer to a more complex 
level for specialized management (acute management by a psychiatrist, and in the long term, rehabilitation due to improper use of alcohol).

- The lack of flexibility in the clinical scenario by healthcare workers towards the incorporation of new practices (the application of the CIWA-AR scale, the administration of a vitamin scheme in patients in whom there is no indication).

- The educational level of the patients, which would be a barrier to adhere to the recommendations given by the health personnel. The available resources according to the General System of Social Security in Health and the Compulsory Health Plan, and the articulation of these with the recommendations proposed in the Alcohol CPG (Barrier of the CPG - alcohol) (Centro Nacional de Investigación en Evidencia y tecnologías en salud Cinets, 2013).

\section{Conclusion}

In all countries of the world, the demand for health services always exceeds the amount of resources available, even in high-income countries (Organización Mundial de la salud, 2011; WHO, 2012). To make the Colombian General Health Security System viable, it is essential, above all, to ensure the collection and proper administration of the financial resources that support the investment and functioning of health care structures and processes (Díaz \& Osorio, 2012; Peñaloza Quintero et al., 2014). But, although, the above is necessary, it is not enough; to reach the equilibrium point of the system implies not only that the contribution and flow of resources is enough, timely and adequate, but also that the expense and investment are reasonable, efficient and proportionate to the available resources.

Thus, CPGs are very useful instruments to assure quality of care and professional self-regulation of health personnel. To the extent that they reduce the undesirable variability in the management of specific clinical conditions and promote the use of care strategies and interventions with scientific evidence on their effectiveness and safety, they not only improve the quality of care and eventually the health outcomes, but must also contribute significantly, but to the reduction of health spending, to the significant improvement of the productive efficiency of the system (Navarro Jimenez, Fontalvo, Laborde, \& et al., 2016).

It is essential to have a process of dissemination, dissemination, implementation, and permanent monitoring of the CPGs in clinical practice. This is a complex process that has only recently been the object of study, and does not have enough evidence in this regard. The process of implementing CPGs is continuous, which must be adapted according to the resources and need of the local context

That is why the adoption of CPG in the clinical - administrative context of ESE Cari neurosciences - including other territorial entities - is a decision that results in the rationalization of human and administrative resources, which unfortunately, will always be insufficient.

\section{Competing Interests Statement}

The authors declare that there are no competing or potential conflicts of interest.

\section{References}

Alcaldía de Barranquilla, González Martínez, S., \& Granados De la Hoz, A. (2014). Análisis de la situación del consumo de sustancias psicoactivas en el distrito de Barranquilla Año 2014. Barranquilla. Retrieved from www.odc.gov.co/Portals/1/modPublicaciones/pdf/CO03942014-consumo-sustancias-psicoactivas-barranqui lla.pdf

Alwan, A. (2011). Global status report on alcohol and health. (W. H. Organization, Ed.). Geneva.

Area de Gestión Clínica de Psiquiatría y Salud Mental - Hospital Universitario 12 de Octubre. (2016). Conductas Adictivas Y Patologia Dual. (Unidad Docente Multiprofesional de Salud Mental, Ed.). Madrid: Hospital $\begin{array}{lllll}\text { Universitario } & 12 & \text { de } & \text { octubre. } & \text { Retrieved }\end{array}$ http://www.madrid.org/cs/Satellite?blobcol=urldata\&blobheader=application\%2Fpdf\&blobheadername $1=\mathrm{C}$ ontent-disposition\&blobheadername $2=$ cadena\&blobheadervalue $1=$ filename\%3DGuíaRot+EIR-Cond+Adict ivas+2016.pdf\&blobheadervalue2=language $\% 3$ Des $\% 26$ site $\% 3$ DHospital12Oc

Caja Costarricense de Seguro Social. (2005). Tratamiento de las Complicaciones de la Dependencia al Alcohol en el Primer y Segundo Nivel de Atención. San José: Caja Costarricense de Seguro Social. Retrieved from $\mathrm{http}: / /$ cochrane.ihcai.org/programa_seguridad_paciente_costa_rica/pdfs/27_Tratamiento-de-las-Complicaci ones-de-la-Dependencia-al-Alcohol.pdf

Cenetec. (2013). Diagnóstico y Tratamiento de la intoxicación aguda por alcohol etílico en el adulto en el segundo 
$y$ tercer nivel de atención. (C. N. de E. T. en Salud, Ed.). México. Retrieved from $\mathrm{http}: / /$ www.cenetec.salud.gob.mx/contenidos/gpc/catalogoMaestroGPC.html

Centro Nacional de Investigación en Evidencia y tecnologías en salud Cinets. (2013). Guía de práctica clínica para la detección temprana, diagnóstico y tratamiento de la fase aguda de intoxicación de pacientes con abuso o dependencia del alcohol. Retrieved from https://www.minsalud.gov.co/sites/rid/Lists/BibliotecaDigital/RIDE/INEC/IETS/GPC_Completa_OH.pdf

Díaz, N. S., \& Osorio, A. D. (2012). Plan de implementación de dos Guías de Práctica Clínica (GPC) contenidas en las Guías de Atención Integral (GAI) en el Sistema General de Seguridad Social en Salud de Colombia: A) "Detección temprana del episodio depresivo y trastorno depresivo recurrente. Revista Colombiana de Psiquiatría, 41(4), 826-841. https://doi.org/10.1016/S0034-7450(14)60049-4

Dirección Nacional de Estupefacientes. (2008). Estudio Nacional de Consumo de Sustancias Psicoactivas en Colombia. Bogotá.

Duarte Osorio, A., Torres Amaya, A. M., \& Vélez, C. M. (2014). Manual de implementación de guías de práctica clínica basadas en evidencia, en instituciones prestadoras de servicios de salud en colombia (1st ed.). Bogotá: Ministerio de Salud Y Protección Social. Retrieved from http://gpc.minsalud.gov.co/herramientas/Pages/default.aspx

Galvin, R., Bråthen, G., Ivashynka, A., Hillbom, M., Tanasescu, R., \& Leone, M. A. (2010). EFNS guidelines for diagnosis, therapy and prevention of Wernicke encephalopathy. European Journal of Neurology, 17(12), 1408-1418. https://doi.org/10.1111/j.1468-1331.2010.03153.x

Guidelines and Protocols Advisory Committee. (2013). BC Guidelines - problem drinking. Retrieved from http://www2.gov.bc.ca/gov/content/health/practitioner-professional-resources/bc-guidelines/problem-drinki ng

Haber, P., Lintzeris, N., Proude, E., \& Lopatko, O. (2009). Guidelines for the Treatment of Alcohol Problems. Sidney.

Lingford-Hughes, A. R., Welch, S., \& Nutt, D. J. (2004). Evidence-Based Guidelines for the Pharmacological Management of Substance Misuse, Addiction and Comorbidity: Recommendations from the British Association for Psychopharmacology. Journal of Psychopharmacology, 18(3), 293-335. https://doi.org/10.1177/026988110401800321

Mayo-Smith, M. F. (2004). Management of Alcohol Withdrawal Delirium $<$ subtitle $>$ An Evidence-Based Practice Guideline $<$ subtitle $>$. Archives of Internal Medicine, $164(13), \quad 1405$. https://doi.org/10.1001/archinte.164.13.1405

Ministerio de Salud y Protección social. (2005). Lineamientos de politica de salud mental para colombia. Cali: Graficas Ltda. Retrieved from https://www.minsalud.gov.co/Lineamientos/Lineamientos -Política\% $252 . .$.

Ministerio de Salud y Protección Social, Fundación Santafe, Grupo de actualización de la Guía Metodológica para el desarrollo de Guías de Práctica Clínica, \& Colombiano Evaluación Económica en el SGSSS. (2014). Guía Metodológica para la elaboración de Guías de Práctica Clínica con Evaluación Económica en el Sistema General de Seguridad Social en Salud Colombiano Versión completa final. (Ministerio de Salud y Protección Social, Ed.) (2nd ed.). Bogotá. Retrieved from gpc.minsalud.gov.co/recursos/

Ministry of Health of New Zealand. (2010). Alcohol and Pregnancy A practical guide for health professionals. Retrieved

from https://www.health.govt.nz/system/files/documents/publications/alcohol-pregnancy-practical-guide-health-p rofessionals.pdf

Monte-Secades, R., Rabuñal-Rey, R., \& Guerrero-Sande, H. (2015). Síndrome de abstinencia alcohólica en pacientes hospitalizados. Revista Clínica Española, 215(2), 107-116. https://doi.org/10.1016/j.rce.2014.11.013

National Health and Medical Research Council. (2009). Australian Guidelines to Reduce Health Risks from https://www.nhmrc.gov.au/_files_nhmrc/publications/attachments/ds10-alcohol.pdf

National Health Committee. (2011). Guidelines for Recognising, Assessing and Treating Alcohol and Cannabis Abuse in Primary Care Guidelines for Recognising, Assessing and Treating Alcohol and Cannabis Abuse in Primary Care. Wellington: National Health Committee. Retrieved from 
http://www.moh.govt.nz/notebook/nbbooks.nsf/0/36F897478F29D84E4C2567E700814E52?OpenDocumen $\mathrm{t}$

National Institute for Health and Clinical Excellence. (2011a). Alcohol-use disorders: diagnosis, assessment and management of harmful drinking and alcohol dependence. Retrieved from https://www.nice.org.uk/guidance/cg115

National Institute for Health and Clinical Excellence. (2011b). Alcohol-use disorders: diagnosis, assessment and management of harmful drinking and alcohol dependence.

Navarro Jimenez, E., Fontalvo, R., Laborde, C., \& et al. (2016). Implementación de la Guía de Práctica Clínica (GPC) para la detección temprana, diagnóstico y atención integral del episodio depresivo y trastorno depresivo recurrente en adultos en el Hospital Universitario Cari ESE Neurociencias de Barranquilla. Salud Uninorte, 32(3). Retrieved from http://rcientificas.uninorte.edu.co/index.php/salud/article/view/8416

Organización Mundial de la salud. (2011). Cerrando la brecha: La política de acción sobre los determinantes sociales de la salud. In Conferencia Mundial sobre los determinantes sociales de la salud (p. 56). Rio de Janeiro.

Organización Panamericana de la Salud OPS/ OMS. (2008). Alcohol y atención primaria de la salud Informaciones clínicas básicas para la identificación y el manejo de riesgos y problemas. Washington, D.C.: OPS. Retrieved from http://www.who.int/substance_abuse/publications/alcohol_atencion_primaria.pdf

Peñaloza Quintero, R., Salamanca Balen, N., Rodríguez Hernández, J., Rodríguez García, J., \& Beltrán Villegas, A. (2014). Estimación de la carga de enfermedad para Colombia, 2010. (Pontificia Universidad Javeriana, Ed.). Bogotá D.C. Retrieved from http://www.javeriana.edu.co/documents/12789/4434885/Carga+de+Enfermedad+Colombia+2010.pdf/e0dbf e7b-40a2-49cb-848e-bd67bf7bc62e

Posada-Villa, José A.; Aguilar-Gaxiola, Sergio A; Magana, Cristina G, Gomez, L. C. (2004). Prevalencia de trastornos mentales y uso de servicios: resultados preliminares del Estudio nacional de salud mental. Colombia, 2003. Revista Colombiana de Psiquiatria, 33(3), 241-262. Retrieved from http://www.scielo.org.co/scielo.php?script=sci_arttext\&pid=S0034-74502004000300002\&lng=en\&nrm=iso $\% 3 \mathrm{E}$

Royal College of Obstetricians and Gynaecologists. (2006). Alcohol consumption and the outcomes of pregnancy. $\begin{array}{lllll}R C O G & \text { Statement } & \text { No. } & 5 . & \text { Retrieved }\end{array}$ http://www.alcoholpolicy.net/files/RCOG_Alcohol_pregnancy_March_06.pdf

SIGN 74. (2015). SIGN 74 (The management of harmful drinking and alcohol dependence in primary care) by kind permission of the Scottish Intercollegiate Guidelines Network. Edinburgh. Retrieved from http://www.careinspectorate.com/images/documents/3210/SIGN_74_The_management_of_harmful_drinki ng_and_alcohol_dependence_in_primary_care_-_Amended.pdf

The Association of Anaesthetists of Great Britain \& Ireland. (2011). Drug and Alcohol Abuse amongst Anaesthetists Guidance Identification and Managemen. https://doi.org/http://dx.doi.org/10.xx36/g.DAAAAA-.2011

U.S. Department of Health And Human Services. (n.d.). Detoxification and Substance Abuse Treatment A Treatment Improvement Protocol TIP, 45. Retrieved from https://www.ncbi.nlm.nih.gov/books/NBK64115/pdf/Bookshelf_NBK64115.pdf

U.S. Preventive Services Task Force. (2013). Alcohol Misuse: Screening and Behavioral Counseling Interventions in Primary Care. Retrieved from https://www.uspreventiveservicestaskforce.org/Page/Document/evidence-summary9/alcohol-misuse-screeni ng-and-behavioral-counseling-interventions-in-primary-care

World Health Organization [WHO]. (2012). Health in the Americas. Washington, D.C.

Wood, V. M. (2008). Guidelines For The Management Of Alcohol Issues In The Acute General Hospital Setting. Doncaster. https://www.alcohollearningcentre.org.uk/_assets/17_Doncaster_Guidelines_For_The_Management_Of_P atients_with_Alcohol_Misuse_In_The_Acute_General_Hospital_Setting.pdf

Yokoyama, A., Matsushita, S., Toyama, T., Nakayama, H., Takimura, T., Kimura, M., ... Yokoyama, T. (2015). [Relapse prevention program consisting of coping skills training, cue exposure treatment, and letter therapy 
for Japanese alcoholic men who relapsed after standard cognitive-behavioral therapy]. Nihon Arukōru Yakubutsu Igakkai Zasshi = Japanese Journal of Alcohol Studies \& Drug Dependence, 50(2), 88-103. Retrieved from http://www.ncbi.nlm.nih.gov/pubmed/26255433

Zaleski, M., Laranjeira, R. R., Marques, A. C. P. R., Ratto, L., Romano, M., Alves, H. N. P., ... Lemos, T. (2006). Diretrizes da Associação Brasileira de Estudos do Álcool e outras Drogas (ABEAD) para o diagnóstico e tratamento de comorbidades psiquiátricas e dependência de álcool e outras substâncias. Revista Brasileira de Psiquiatria, 28(2), 142-148. https://doi.org/10.1590/S1516-44462006000200013

\section{Copyrights}

Copyright for this article is retained by the author(s), with first publication rights granted to the journal.

This is an open-access article distributed under the terms and conditions of the Creative Commons Attribution license (http://creativecommons.org/licenses/by/4.0/). 